\title{
Diet, Exercise and the Metabolic Syndrome
}

\author{
Christos Pitsavos $^{1}$, Demosthenes Panagiotakos ${ }^{2}$, Michael Weinem ${ }^{3}$ and Christodoulos Stefanadis ${ }^{1}$
}

\author{
${ }^{1}$ First Cardiology Clinic, School of Medicine, University of Athens, Athens, Greece. ${ }^{2}$ Department of Nutrition and Dietetics, \\ Harokopio University, Athens, Greece. ${ }^{3}$ Society for Biomedical Diabetes Research, Duisburg, Germany. Address correspondence to: \\ Demosthenes B. Panagiotakos, e-mail: d.b.panagiotakos@usa.net
}

\begin{abstract}
The metabolic syndrome is a combination of metabolic disorders, such as dyslipidemia, hypertension, impaired glucose tolerance, compensatory hyperinsulinemia and the tendency to develop fat around the abdomen. Individuals with the metabolic syndrome are at high risk for atherosclerosis and, consequently, cardiovascular disease. However, as a result of several epidemiologic studies and some clinical trials, it has
\end{abstract}

\section{Defining the metabolic syndrome}

g he metabolic syndrome is a collection of conditions associated with metabolic disorder and increased risk of developing cardiovascular disease. Conditions such as dyslipidemia, high blood pressure, impaired glucose tolerance and abdominal fat accumulation fall into this category [1-5]. Investigations were aimed at the establishment of a quantitative definition for the associated conditions. However, these efforts led to multiple definitions that are partly inconsistent and disputed.

The metabolic syndrome was first described in the 1940s by Jean Vague, who linked abdominal obesity to metabolic abnormalities. Three decades later, in the 1970s, Gerald Phillips, suggested that aging, obesity and sex hormone-associated clinical manifestations, now referred to as the metabolic syndrome, are associated with heart disease [1]. More recently, in 1988, Gerald Reaven proposed insulin resistance, and not obesity, as the critical factor and named the constellation been suggested that people with the metabolic syndrome may benefit from intensive lifestyle modifications including dietary changes and adopting a physically more active lifestyle. In this review we summarize the effects of diet and physical activity on the development of the metabolic syndrome.

Keywords: metabolic syndrome $\cdot$ diet $\cdot$ exercise $\cdot$ lifestyle

of abnormalities Syndrome-X [2]. However, the most widely used definitions were established by the World Health Organization (WHO) and the National Cholesterol Education Program Adult Treatment Panel III (NCEP ATPIII). These organizations regarded the metabolic syndrome as a cardiovascular risk factor beside elevated low-density lipoprotein (LDL) cholesterol $[6,7]$. Atherogenic dyslipidemia (a prothrombotic state), insulin resistance, hypertension, abdominal obesity and elevated levels of various inflammatory markers were then regarded as the prominent characteristics of the metabolic syndrome [8]. Kim and Reaven claimed that although WHO and NCEP ATPIII use the same term to define this condition (i.e., metabolic syndrome), both pursue different diagnostic aims and use different criteria to identify individuals, which relate to their different institutional goals [9]. In contrast to the WHO definition, the NCEP ATPIII does not include the measurement of insulin and therefore may fail to detect insulin resistance. Nevertheless, the NCEP ATPIII definition appears to be more predic- 
tive regarding the risk of developing the syndrome than the WHO definition, i.e. failure to detect insulin resistance need not be a disadvantage.

In 2005, the International Diabetes Federation (IDF) Epidemiology Task Force suggested a new definition for the metabolic syndrome, focusing on central obesity [10]. Comparing the three definitions with respect to their areas of use, the WHO criteria appear to be more suitable for research purposes, while the NCEP ATPIII and IDF criteria seem to be more useful for clinical practice. The latter require only fasting assessments of blood samples, while WHO criteria require oral glucose tolerance tests, which can meaningfully confirm insulin resistance but are less practical in epidemiological or clinical studies. In general, the NCEP ATPIII and IDF definitions give more weight to obesity and sedentary lifestyle, whereas the WHO emphasizes the importance of insulin resistance as an underlying etiology of the metabolic syndrome. The common feature of all three definitions is that the definition of the metabolic syndrome should include characteristics of atherogenic dyslipidemia, insulin resistance, hypertension and obesity. However, only the IDF definition considers obesity as a prerequisite and takes into account that obesity in Asian and other populations differs in its definition from obesity in Europeans [10]. Nevertheless, each of the defining abnormalities may promote atherosclerosis independently, but when clustered together, these metabolic disorders, beside elevated LDL cholesterol, are increasingly atherogenic and may substantially enhance the risk of cardiovascular disease. Because each independent factor of the metabolic syndrome can increase the individual's cardiovascular risk, an integrated and comprehensive approach is necessary for people afflicted with the syndrome.

It is now widely accepted that the treatment of hypertension, obesity and dyslipidemia should be primarily based on weight-loss diets and exercise programs to increase physical activity and to ameliorate progress of the symptoms. In this review we present a summary and assessment of the existing research regarding interventions in the metabolic syndrome and of epidemiologic studies on diet and exercise in relation to the prevalence of the metabolic syndrome (or diabetes, which may lead to the development of the syndrome).

\section{Epidemiology of the metabolic syndrome}

In this section, we review studies on lifestyle changes and metabolic syndrome. However, first we examine the prevalence of this condition at the population level. It is supposed that a substantial proportion of individuals living in Western nations are afflicted with multiple metabolic abnormalities [3]. A recently published report by the NCEP ATPIII estimates that at least 47 million Americans are afflicted with this condition and projects the number of US citizens with metabolic syndrome to be between 50 to 75 million in 2010 [11]. Considering Europe, $\mathrm{Hu}$ et al. from the DECODE Study group reported that the agestandardized prevalence of the metabolic syndrome was $15.7 \%$ in men and $14.2 \%$ in women [12]. For the Mediterranean region, Ferrannini et al. estimated that more than $70 \%$ of adults have at least one of the major characteristics of the metabolic syndrome [13]. In this context, the AT'TICA Study, comprising 1,500 women and men from Greece, estimated the prevalence of the metabolic syndrome at $25 \%$ in men and $15 \%$ in women [14]. Recently, Athyros et al., who considered a Northern Greek population, reported that the ageadjusted prevalence of the NCEP ATP III-defined metabolic syndrome was $25 \%$ whereas the IDFdefined prevalence was $43 \%$ [15]. Furthermore, the prevalence of the metabolic syndrome in a Portuguese population was $27 \%$ in women and $19 \%$ in men [16]. A very similar result was derived from an examination of a Korean population, where the prevalence of the metabolic syndrome was $29 \%$ in men and $17 \%$ in women [17], while in another study of the same population the prevalence of the syndrome was only $13 \%$ in both men and women [18]. Differences in genetic background, dietary habits, levels of physical activity, population age and sex structure and levels of overand under-nutrition may influence the prevalence of both the metabolic syndrome and its components worldwide. Nevertheless, all these epidemiologic studies suggest that the prevalence of the syndrome is high worldwide. This could be due to increasing obesity and sedentary lifestyles and reflect the growing necessity for therapeutic intervention.

\section{The role of diet in the treatment of the meta- bolic syndrome}

The NCEP ATPIII suggested therapeutic lifestyle changes (TLC) in order to reduce the prevalence of the metabolic syndrome [11]. Among several factors related to lifestyle habits the beneficial effect of diet has already been highlighted in many clinical and epidemiological studies [19-29]. During the last decades increasing scientific evidence has emerged that protective health effects can be obtained from diets that are rich in fruits, vegetables, legumes and whole grains, and which include fish, nuts, and low-fat dairy products. Such diets need not be restricted in total fat in- 
take as long as energy intake does not exceed caloric expenditure and if they emphasize predominantly vegetable oils that have a low content of saturated fats and partially hydrogenated oils. As the intake of specific nutrients may have different effects on the development of metabolic syndrome characteristics the following sections focus on separate nutrient groups in order to clarify their roles in disease and treatment.

Table 1. Summary of selected studies evaluating dietary habits in relation to the metabolic syndrome or associated conditions

\begin{tabular}{|c|c|c|c|}
\hline Study & Design & $\begin{array}{l}\text { Sample } \\
\text { and gender }\end{array}$ & Outcome \\
\hline Panagiotakos et al. [14] & Cross-sectional & $\begin{array}{l}3,042 \text { men and } \\
\text { women }\end{array}$ & $\begin{array}{l}\text { Decreased risk of having } \\
\text { the metabolic syndrome } \\
\text { due to Mediterranean diet }\end{array}$ \\
\hline Keys et al. [20] & $\begin{array}{l}\text { Prospective } \\
\text { FU: } 15 \mathrm{yr}\end{array}$ & 11,579 men & $\begin{array}{l}\text { Increased risk of CHD } \\
\text { mortality due to saturated } \\
\text { fat } \\
\text { Decreased CHD risk due } \\
\text { to monounsaturated fat }\end{array}$ \\
\hline Trichopoulou et al. [21] & $\begin{array}{l}\text { Prospective } \\
\text { FU: } 5 \mathrm{yr}\end{array}$ & $\begin{array}{l}182 \text { elderly men } \\
\text { and women }\end{array}$ & $\begin{array}{l}\text { Reduced risk of mortality } \\
\text { due to Mediterranean diet }\end{array}$ \\
\hline De Lorgeril et al. [26] & $\begin{array}{l}\text { Randomized clinical } \\
\text { trial }\end{array}$ & $\begin{array}{l}605 \text { myocardial in- } \\
\text { farction survivors }\end{array}$ & $\begin{array}{l}\text { Reduced risk of CHD } \\
\text { mortality due to Mediter- } \\
\text { ranean diet }\end{array}$ \\
\hline $\begin{array}{l}\text { Martinez-Gonzalez et al. } \\
\text { [26] }\end{array}$ & $\begin{array}{l}\text { Case-control } \\
\text { FU: } 14 \text { yr }\end{array}$ & $\begin{array}{l}171 \text { myocardial in- } \\
\text { farction patients } \\
\text { and } 171 \text { controls }\end{array}$ & $\begin{array}{l}\text { Reduced risk of CHD } \\
\text { risk due to Mediterranean } \\
\text { diet }\end{array}$ \\
\hline Trichopoulou et al. [28] & $\begin{array}{l}\text { Prospective } \\
\text { FU: } 44 \text { mo }\end{array}$ & $\begin{array}{l}22,043 \text { men and } \\
\text { women }\end{array}$ & $\begin{array}{l}\text { Reduced risk of CHD } \\
\text { mortality due to Mediter- } \\
\text { ranean diet }\end{array}$ \\
\hline
\end{tabular}

Legend: CHD: coronary heart disease. FU: follow-up.

\section{Nutrients and the metabolic syndrome}

Carbohydrate consumption has been a critical factor blamed for weight gain, obesity, diabetes, and a number of other diseases. It is important to recognize that such problems may be associated with the excess consumption of the wrong carbohydrates such as simple sugars (i.e., table sugar), but not with complex carbohydrates. Large proportions of complex carbohydrates (such as potatoes, breads, corn, etc.) in the diet are recommended.

High-fiber diets have received considerable attention in recent years due to their association with decreased incidence of several metabolic disorders such as hypertension, diabetes, obesity, as well as heart disease and colon cancer.
Fat is a general term used to refer to oils, fats and waxes. Usually the daily energy intake consists of $30 \%$ fat, but no more than $10 \%$ of these calories should come from saturated (animal) fats. The residual energy should be obtained from polyunsaturated or monounsaturated oils [27]. Saturated fats promote dyslipidemias and, consequently atherogenesis. The consumption of unsaturated fats, derived mostly from vegetable oils such as safflower, corn, olive and soybean oil, may be able to prevent serious disorders, such as atherogenesis, hypertension and consequently the metabolic syndrome.

Nutritional studies suggest that we only need relatively small amounts of protein for good health. The requirements for adults are 0.8 grams per kilogram of body weight. Increased protein intake may be detrimental for obese persons and those with kidney disease [30]. See Table 1 for a summary on studies evaluating dietary habits in relation to the metabolic syndrome or associated conditions.

\section{Dietary patterns}

Diets should include a balanced intake of nutrient elements [27]. During the past two decades a large body of evidence has related balanced dietary patterns, such as the Mediterranean, to lower mortality rates, decreased prevalence of some metabolic disorders (obesity, high blood pressure), as well as lower incidence of coronary heart disease and various types of cancer.

The Mediterranean dietary pattern has received much attention in the last ten years [22, 24-29, 31]. It is characterized by the use of olive oil, which is important not only because it has several beneficial properties, but also because it allows the consumption of large quantities of vegetables in the form of salads and equally large quantities of legumes in the form of cooked foods. Other essential components of the Mediterranean diet are wheat, olives and grapes, and their various derivative products. Total lipid intake may be high - around or in excess of $40 \%$ of total en- 
ergy intake - however, the ratio of monounsaturated to saturated fats is much higher in the Mediterranean regions than in other places of the world. A potential explanation for the beneficial effect of this dietary pattern on human health is that it is low in saturated fat, high in monounsaturated fat, mainly from olive oil, high in complex carbohydrates from legumes, and high in fiber, mostly from vegetables and fruits. The high content of vegetables, fresh fruits, cereals and olive oil guarantees a high intake of beta-carotene, vitamins $\mathrm{C}$ and $\mathrm{E}$, polyphenols and various important minerals. These key elements have been suggested to be responsible for the beneficial effect of this diet on human health [22]. Interestingly, during the last years, several researchers have associated the Mediterranean diet with improvements in the blood lipid profile (in particular HDL cholesterol and oxidized LDL), decreased risk of thrombosis (i.e., fibrinogen levels), improvements in endothelial function and insulin resistance, reduction in plasma homocysteine concentrations, and a decrease in body fat [24-29, 31].

Furthermore, antioxidants represent a common element in the Mediterranean diet and antioxidant action provides a plausible explanation for its apparent benefits [27]. It is known that wild edible greens frequently eaten in the form of salads and pies contain very high quantities of flavonoids. Although there is no direct evidence that these antioxidants are central to the benefits of the Mediterranean diet, indirect evidence from epidemiological data and an increasing understanding of their mechanisms of action suggest that antioxidants may play a major role. Recently, the ATTICA Study investigators showed that adherence to the Mediterranean diet was associated with $20 \%$ lower odds of having the metabolic syndrome, irrespective of age, sex, physical activity, lipids and blood pressure levels [14].

\section{The role of exercise}

In the late 1970 s several observational studies suggested that mortality or morbidity caused by atherosclerotic disease was inversely related to the individual's physical activity status [32-40]. Even though exercise is considered a cornerstone in the treatment of diabetes, a condition that is strongly related to metabolic syndrome, only a few studies have investigated its relationship with cardiovascular disease risk in diabetic persons. In a sample of 492 diabetic men and women from the National Health and Nutrition Examination Survey, followed-up for 2 years, Ford and DeStefano [36] found that inactivity in non-leisure time was sig- nificantly associated with higher rates of coronary death. Data from an average 8.2-year, prospective, follow-up of 8,715 men in a preventive medicine clinic in the USA demonstrated a higher risk of all-cause mortality for unfit compared to fit persons, within each of three glycemic status levels [37]. See Table 2 for a summary of studies evaluating physical activity in relation to the metabolic syndrome or associated conditions.

In a sample of 1,263 diabetic men, followed-up for 12 years in the Aerobics Center Longitudinal Study, participants who reported being sedentary had an adjusted risk for mortality of 1.7 compared to those who were physically active [38]. In another sample of 5,125 diabetic nurses from the Nurses Health Study, after 14 years of follow-up, the investigators found a $45 \%$ multivariate-adjusted reduction in cardiovascular disease risk with moderate to vigorous activity compared to sedentary [39]. The Whitehall Cohort Study investigated the relation of two indices of physical activity walking pace and leisure activity - to total mortality, coronary heart disease and other cardiovascular diseases, in a 25-years follow-up of 6,408 male British civil servants [40]. Among 352 diabetic men and 6,056 non-diabetics at study entry, the investigators found that the two indices of physical activity were inversely related to all-cause, coronary heart disease and other cardiovascular disease mortalities in both normoglycemic men and men with diabetes/impaired glucose tolerance.

More recently, Tanasescu et al. [41] from the Health Professionals' Study, during a 14-year follow-up of 2803 men, observed a 42\% multivariate-adjusted reduction of total mortality and a $33 \%$ multivariateadjusted reduction of cardiovascular disease incidence in the highest quintile of physical activity compared with the lowest.

The Finish Diabetes Prevention Study (DPS), a randomized clinical trial including 522 men and women with impaired glucose tolerance, intended to investigate if leisure-time physical activity is associated with the prevalence of type 2 diabetes [42]. The goal for physical activity in leisure times was an exercise of $\geq 30 \mathrm{~min} /$ day. The study showed that people with increased moderate-to-vigorous leisure time physical activity were $65 \%$ less likely to develop diabetes after various adjustments for changes in diet and body weight. In a similar study, the Diabetes Prevention Program (DPP) included 3,234 obese subjects with impaired glucose tolerance but not diabetes and randomized them to metformin, lifestyle changes (diet and exercise) and placebo [43]. The investigators in- 
troduced a lifestyle-modification program with the goals of at least a 7 percent weight loss and a physical activity of $\geq 150 \mathrm{~min} / \mathrm{wk}$. It could be observed that both treatments, lifestyle changes and metformin, were significantly different to placebo. However, lifestyle changes were more effective than metformin with a reduced incidence of diabetes of 58\% (lifestyle) compared to $31 \%$ (metformin) [43].

In contrast to the number of studies that investigated the association of exercise with the development of diabetes or cardiovascular disease, data considering specifically the metabolic syndrome are sparse in the literature. One of the epidemiologic studies that evaluated the association between physical activity and the prevalence of the metabolic syndrome was the ATTICA Study [14]. The results showed that even light- to-moderate leisure time physical activity $(<7 \mathrm{kcal} / \mathrm{min}$ expended) was associated with a considerable reduction in the prevalence of the metabolic syndrome in 3042 men and women from the general population. Regular, intensive exercise was associated with a much greater decrease [14]. In addition, the ATTICA Study investigators demonstrated that the adoption of the Mediterranean diet by physically active people was associated with greater reduction in the odds of having the syndrome than diet or exercise alone, after adjusting for several potential confounders. Thus, the combination of beneficial health factors in terms of nutrition and exercise explained at least a part of the reduction in the prevalence of the metabolic syndrome; and this effect still remained beneficial when considering differences in lipids as well as inflammation and coagu-

Table 2. Summary of studies evaluating physical activity in relation to the metabolic syndrome or associated conditions

\begin{tabular}{|c|c|c|c|}
\hline Study & Design & $\begin{array}{l}\text { Sample } \\
\text { and gender }\end{array}$ & Outcome \\
\hline Ford et al., 1991 [36] & $\begin{array}{l}\text { Prospective } \\
\text { FU: } 2 \mathrm{yr}\end{array}$ & $\begin{array}{l}492 \text { diabetic men } \\
\text { and women }\end{array}$ & $\begin{array}{l}\text { Decreased risk of CHD mortality due } \\
\text { to any type physical activity }\end{array}$ \\
\hline Kohl et al., 1992 [37] & $\begin{array}{l}\text { Prospective } \\
\text { FU: } 8.2 \mathrm{yr}\end{array}$ & 8,715 men & $\begin{array}{l}\text { Decreased risk of mortality in diabet- } \\
\text { ics due to leisure type of physical ac- } \\
\text { tivity }\end{array}$ \\
\hline $\begin{array}{l}\text { Da Qing IGT and Diabetes } \\
\text { Study, } 1997 \text { [63] }\end{array}$ & $\begin{array}{l}\text { Prospective } \\
\text { FU: } 6 \mathrm{yr}\end{array}$ & $\begin{array}{l}577 \text { men and women } \\
\text { with IGT }\end{array}$ & $\begin{array}{l}\text { Decreased risk of developing T2DM } \\
\text { due to physical activity and diet }\end{array}$ \\
\hline $\begin{array}{l}\text { Malmo Preventive Trial, } \\
1998 \text { [62] }\end{array}$ & $\begin{array}{l}\text { Prospective } \\
\text { FU: } 12 \mathrm{yr}\end{array}$ & $\begin{array}{l}288 \text { men and women } \\
\text { with IGT }\end{array}$ & $\begin{array}{l}\text { Decreased risk of developing T2DM } \\
\text { due to physical activity and diet }\end{array}$ \\
\hline Wein et al., 1999 [64] & $\begin{array}{l}\text { Prospective } \\
\text { FU: } 6 \text { yr }\end{array}$ & $\begin{array}{l}200 \text { men and women } \\
\text { with IGT }\end{array}$ & $\begin{array}{l}\text { Decreased risk of developing T2DM } \\
\text { due to physical activity and diet }\end{array}$ \\
\hline Wei et al., 2000 [38] & $\begin{array}{l}\text { Prospective } \\
\text { FU: } 12 \mathrm{yr}\end{array}$ & $\begin{array}{l}1,263 \text { diabetic } \\
\text { men }\end{array}$ & $\begin{array}{l}\text { Decreased risk of mortality due to } \\
\text { leisure type of physical activity }\end{array}$ \\
\hline Hu et al., 2001 [39] & $\begin{array}{l}\text { Prospective } \\
\text { FU: } 14 \mathrm{yr}\end{array}$ & 5,125 diabetic women & $\begin{array}{l}\text { Reduced CVD risk due to leisure type } \\
\text { of physical activity }\end{array}$ \\
\hline Batty et al., 2002 [40] & $\begin{array}{l}\text { Prospective } \\
\text { FU: } 25 \mathrm{yr}\end{array}$ & 352 diabetic men & $\begin{array}{l}\text { Reduced risk of CHD and CVD mor- } \\
\text { tality due to leisure type of physical } \\
\text { activity }\end{array}$ \\
\hline Tanasescu et al., 2003 [41] & $\begin{array}{l}\text { Prospective } \\
\text { FU: } 14 \mathrm{yr}\end{array}$ & $\begin{array}{l}2,803 \text { diabetic } \\
\text { men }\end{array}$ & $\begin{array}{l}\text { Reduced risk of CHD, and CVD } \\
\text { mortality and morbidity due to any } \\
\text { type of physical activity }\end{array}$ \\
\hline $\begin{array}{l}\text { Finnish Diabetes Prevention } \\
\text { Study, } 2001 \text { [42] }\end{array}$ & $\begin{array}{l}\text { Prospective } \\
\text { FU: } 3.2 \mathrm{yr}\end{array}$ & 522 men and women & $\begin{array}{l}\text { Reduced risk of diabetes due to } \\
\text { physical activity and diet }\end{array}$ \\
\hline $\begin{array}{l}\text { Diabetes Prevention } \\
\text { Program, } 2002 \text { [43] }\end{array}$ & $\begin{array}{l}\text { Prospective } \\
\text { FU: } 2.8 \mathrm{yr}\end{array}$ & $\begin{array}{l}3,234 \text { obese men } \\
\text { and women }\end{array}$ & $\begin{array}{l}\text { Reduced risk of diabetes due to } \\
\text { physical activity and diet }\end{array}$ \\
\hline $\begin{array}{l}\text { Panagiotakos et al., } 2004 \\
\text { [14] }\end{array}$ & Cross-sectional & 2,282 men and women & $\begin{array}{l}\text { Reduced odds of metabolic syndrome } \\
\text { due to any type of physical activity }\end{array}$ \\
\hline
\end{tabular}

Legend: All studies included both exercise and diet advice. IGT: impaired glucose tolerance. CHD: coronary heart disease. CVD: cardiovascular disease. FU: follow-up. 
lation factors [44].

The level of physical activity needed for a beneficial impact on coronary risk remains controversial. The Center for Disease Control and Prevention and the American College of Sports Medicine recommend the accumulation of at least 30 minutes of moderateintensity physical activity (equivalent to brisk walking at 3-4 mph), on most, preferably all, days of the week on the basis of documented improvements in fitness, for the general population [45]. This level of activity is well tolerated by most middle-aged or older individuals. However, people who are initially unfit or sedentary should start at lower intensity. Nevertheless, it could be strongly suggested that even low levels of physical activity may modify the status of the clinical and biochemical components of the metabolic syndrome and, therefore reduce its prevalence in the population [45].

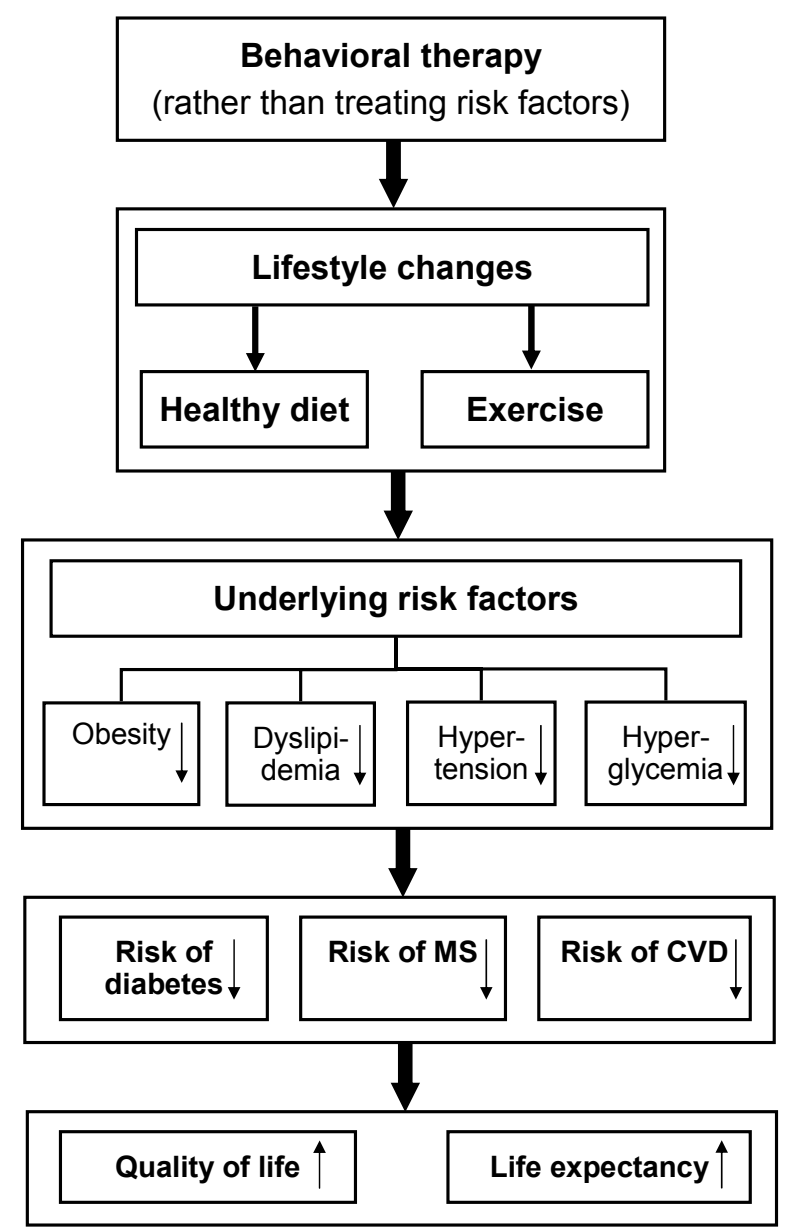

Figure 1. A conceptual model for lifestyle changes and better health. MS: metabolic syndrome. CVD: cardiovascular disease.
The protective role of physical activity has been attributed to various mechanisms. On the one hand, physical exercise has favorable effects on traditional cardiovascular risk factors; on the other, the positive effect can be attributed to a direct action of physical activity on the heart itself leading to increased myocardial oxygen supply, decreased myocardial oxygen demands, formation of collateral coronary circulation, improved myocardial contraction and electrical stability of the heart [45].

The theoretical mechanism for chronic exercise promoting a reduction in body fat involves increased total daily energy expenditure without a corresponding increase in energy intake. It is generally accepted that long-term physical activity of sufficient intensity, duration and frequency has a favorable effect on weight reduction and body fat distribution. Evidence supports the hypothesis that the effectiveness of exercise to induce weight loss is directly related to the initial degree of obesity and the total amount of energy expenditure [46].

The beneficial effect of physical activity on blood pressure levels has also been shown [47-49]. In particular, it is now accepted that moderate levels of exercise can significantly decrease blood pressure in patients with mild to moderate essential hypertension.

Although physical activity has an insignificant effect on blood lipid levels, some investigators have shown the overall benefit of physical activity in modifying blood lipid profiles. The Pawtucket Heart Study group reported that physical activity was significantly associated with higher HDL-cholesterol levels [49]. Moreover, among 3,000 adult Japanese men the frequency of physical activity was independently and positively related to HDL-cholesterol [50]. Similarly, a pooled analysis among three European cohorts consisting of elderly men demonstrated a significant relation between physical activity and HDL-cholesterol [51]. Reports by Ford [52], and King [53] studying approximately 14,000 adult participants in the National Health and Nutrition Examination Survey III (1988-1994) showed that the time devoted to physical activity was inversely associated with some inflammatory marker levels, such as C-reactive protein, plasma fibrinogen concentration and the number of white blood cells, after adjusting for several potential confounders. Similarly, Abramson et al. [54] reported that physical activity was independently associated with a lower probability of having elevated inflammatory marker levels among healthy US adults aged 40 years and older, independent of several confounding factors. An inverse relation between plasma fibrinogen levels and leisure 
time physical activity has also been reported by several others [55-58] (Table 2).

Lifestyle approaches to treating and preventing the metabolic syndrome vary, but nearly all experts agree that parameters involved in the syndrome are greatly improved by reducing body weight and increasing the level of physical activity (Figure 1). Recently, Roberts $e t$ al. [59] and Stone et al. [60] revealed by an extensive review of the literature that lifestyle modifications mitigated disease progression and reversed existing disease. Small changes can lead to great improvements, not for achieving a perfect lifestyle but for working towards a better and healthier one. However, it should be noted that although lifestyle changes can provide many benefits for human health, and especially for the management of the metabolic syndrome, sometimes these changes are difficult to implement and maintain. Therefore, drug treatment including statins, ACE inhibitors, angiotensin-II receptor blockers, and oral antidiabetic agents can be considered. It has been shown that these drugs are able to reduce effectively

\section{References}

1. Phillips GB. Sex hormones, risk factors and cardiovascular disease. Am J Med 1978. 65:7-11.

2. Reaven GM. Role of insulin resistance in human disease. Diabetes 1988. 37:1595-607.

3. Grundy SM. Obesity, metabolic syndrome and cardiovascular disease. J Clin Endocrinol Metab 2004. 89:2595-600.

4. Ford ES, Giles WH, Dietz WH. Prevalence of the metabolic syndrome among US adults: findings from the third National Health and Nutrition Examination Survey. JAMA 2002. 287:356-359.

5. Das UN. Metabolic syndrome X: an inflammatory condition? Curr Hypertens Rep 2004. 6:66-73.

6. Alberti KG, Zimmet P. Definition, diagnosis and classification of diabetes mellitus and its complications. Part 1: diagnosis and classification of diabetes mellitus provisional report of a WHO consultation. Diabet Med 1998. 15:539-53.

7. Grundy SM, Cleeman JI, Daniels SR, Donato KA, Eckel RH, Franklin BA, Gordon DJ, Krauss RM, Savage PJ, Smith SC Jr, Spertus JA, Costa F. Diagnosis and Management of the Metabolic Syndrome. An American Heart Association/National Heart, Lung, and Blood Institute Scientific Statement. Circulation 2005. 112(17):2735-2752.

8. Haffner SM. The metabolic syndrome: inflammation, diabetes mellitus, and cardiovascular disease. Am J Cardiol 2006. 97(2A):3A-11A.

9. Kim SH, Reaven GM. The metabolic syndrome: one step forward, two steps back. Diab Vasc Dis Res 2004. 1:68-75.

10. Alberti KG, Zimmet P, Shaw J; IDF Epidemiology Task Force Consensus Group. The metabolic syndrome - a new worldwide definition. Lancet 2005. 366:1059-1062.

11. Executive Summary of the Third Report of the National Cholesterol Education Program (NCEP) Expert Panel on Detection, Evaluation, and Treatment of High Blood Cholesterol in Adults (Adult Treatment Panel III). JAMA 2001. 285:2486- the levels of underlying risk factors for the metabolic syndrome such as dyslipidemia, hypertension, hyperglycemia and the risk of developing diabetes [61].

\section{Concluding remarks}

The metabolic syndrome seems to be an emerging epidemic that affects roughly one out of five persons in Western industrialized countries. Similar to other chronic diseases, the metabolic syndrome is a complex, lifestyle-dependent illness. Its solution is not difficult to achieve: eat less, exercise more. These solutions must become part of everyday life and be woven into our social life to be effective. Health care professionals need to help people to understand the potential benefits that may result from the introduction of dietary patterns and exercise, and support them in adopting and adhering to these behavioral patterns. Actually, society as a whole needs to acquire a profound consciousness of the relevance for health of lifestyle factors such as nutrition and activity.

2497.

12. Hu G, Qiao Q, Tuomilehto J, Balkau B, Borch-Johnsen K, Pyorala K; DECODE Study Group. Prevalence of the metabolic syndrome and its relation to all-cause and cardiovascular mortality in non-diabetic European men and women. Arch Intern Med 2004. 164:1066-1076.

13. Ferrannini E, Natali A. Essential hypertension, metabolic disorders, and insulin resistance. Am Heart J 1991. 121:12741282.

14. Panagiotakos DB, Pitsavos CH, Chrysohoou C, Skoumas J, Tousoulis D, Toutouza M, Toutouzas PK, Stefanadis C. The Impact of Lifestyle Habits on the Prevalence of the Metabolic Syndrome among Greek adults from the ATTICA study. Am Heart J 2004. 147:106-112.

15. Athyros VG, Ganotakis ES, Elisaf M, Mikhailidis DP. The prevalence of the metabolic syndrome using the National Cholesterol Educational Program and International Diabetes Federation definitions. Curr Med Res Opin 2005. 21:1157-1159.

16. Santos AC, Lopes C, Barros H. Prevalence of metabolic syndrome in the city of Porto. Rev Port Cardiol 2004. 23:45-52.

17. Oh JY, Hong YS, Sung YA, Barrett-Connor E. Prevalence and factor analysis of metabolic syndrome in an urban Korean population. Diabetes Care 2004. 27:2027-2032.

18. Lee WY, Park JS, Noh SY, Rhee EJ, Kim SW, Zimmet PZ. Prevalence of the metabolic syndrome among 40,698 Korean metropolitan subjects. Diabetes Res Clin Pract 2004. 65:143-149.

19. Kannel WB, McGee DL, Gordon T. A general cardiovascular risk profile: The Framingham Study. Am J Cardiol 1976. 38:46-51.

20. Keys A, Menotti A, Karvonen MJ, Aravanis C, Blackburn H, Buzina R, Djordjevic BS, Dontas AS, Fidanza F, Keys MH, et al. The diet and 15-year death rate in the Seven Countries Study. Am J Epidemiol 1986. 124:903-915.

21. Trichopoulou A, Kouris-Blazos A, Wahlqvist M, Trichopoulos D. Diet and overall survival in elderly people. Br Med J 1995. 311:1457-1460. 
22. Trichopoulou A., Lagiou P. Healthy traditional Mediterranean diet - An expression of culture, history and lifestyle. Nutr Rev 1997. 55:383-389.

23. Knapp HW. Dietary fatty acids in human thrombosis and homeostasis. Am I Clin Nutr 1997. 65:1687S-1698S.

24. de Lorgeril M, Salen P, Martin JL, Monjaud I, Delaye J, Mamelle N. Mediterranean diet, traditional risk factors, and the rate of cardiovascular complications after myocardial infarction: final report of the Lyon Diet Heart Study. Circulation. 1999;99:779-85.

25. Panagiotakos DB, Pitsavos C, Chrysohoou C, Tzioumis K, Papaioannou I, Stefanadis C, Toutouzas PK. The Association of Mediterranean Diet with Lower Risk of Acute Coronary Syndromes, in Hypertensive Subjects. Int J Cardiol 2002. 19:141-147.

26. Martinez-Gonzalez MA, Fernandez-Jarne E, SerranoMartinez M. Mediterranean diet and reduction in the risk of a first acute myocardial infarction: an operational healthy dietary score. Eur J Nutr 2002. 41:153-160.

27. World Health Organization Study Group. Diet, Nutrition, and the Prevention of Chronic Diseases. Geneva, Switzerland, World Health Organization, Technical Report Series, 916, 2003.

28. Trichopoulou A, Costacou T, Bamia C, Trichopoulos D. Adherence to a Mediterranean diet and survival in a Greek population. N Engl J Med 2003. 348:2599-2608.

29. Chrysohoou C, Panagiotakos DB, Pitsavos C, Das UN, Stefanadis C. Adherence to the Mediterranean diet attenuates inflammation and coagulation process, in healthy adults: the ATTICA study. I Am Col Cardiol 2004. 44:152-158.

30. Anderson CA, Miller ER 3rd. Dietary recommendations for obese patients with chronic kidney disease. Adv Chronic Kidney Dis 2006. 13(4):394-402.

31. Schroder H, Marrugat J, Vila J, Covas MI, Elosua R. Adherence to the traditional Mediterranean diet is inversely associated with body mass index and obesity in a Spanish population. J Nutr 2004. 134:3355-3361.

32. American College of Sports Medicine. Position statement on proper and improper weight loss programs. 1983. 15:9-13.

33. Leon A S, Connett J, Jacobs DR. Leisure-time physical activity levels and risk of coronary heart disease and death: the Multiple Risk Factor Intervention Trial. JAMA 1987. 258:23882395.

34. Pekkanen J, Marti B, Nissinen A. Reduction of premature mortality by high physical activity: a 20 -year follow-up of middle-aged Finnish men. Lancet 1987. 255:1473-1477.

35. Pate RR, Pratt M, Blair SN, Haskell WL. Physical activity and public health. JAMA 1995. 273:402-407.

36. Ford ES, DeStefano F. Risk factors for mortality from all causes and from coronary heart disease among persons with diabetes. Findings from the National Health and Nutrition Examination Survey I Epidemiologic Follow-up Study. Am J Epidemiol 1991. 133:1220-1230.

37. Kohl HW, Villegas JA, Gordon NF, Blair SN. Cardiorespiratory fitness, glycemic status and mortality risk in men. Diabetes Care 1992. 15:184-192.

38. Wei M, Gibbons LW, Kampert JB. Low cardiorespiratory fitness and physical inactivity as predictors of mortality in men with type 2 diabetes. Ann Intern Med 2000. 132:605-611.

39. Hu FB, Stampfer MJ, Solomon C. Physical activity and risks for cardiovascular events in diabetic women. Ann Intern Med 2001. 134:96-105.

40. Batty GD, Shipley MJ, Marmot M, Smith GD. Physical ac- tivity and cause-specific mortality in men with type 2 diabetes/impaired glucose tolerance: evidence from the Whitehall study. Diabet Med 2002. 19:580-588.

41. Tanasescu M, Leitzmann MF, Rimm EB, Hu FB. Physical activity in relation to cardiovascular disease and total mortality among men with type 2 diabetes. Circulation 2003. 107:24352439.

42. Tuomilehto J, Lindstrom J, Eriksson JG, Valle TT, Hamalainen H, Ilanne-Parikka P, KeinanenKiukaanniemi S, Laakso M, Louheranta A, Rastas M, Salminen V, Uusitupa M, Finnish Diabetes Prevention Study Group. Prevention of type 2 diabetes mellitus by changes in lifestyle among subjects with impaired glucose tolerance. N Engl J Med 2001. 344(18):1343-1350.

43. Knowler WC, Barrett-Connor E, Fowler SE, Hamman RF, Lachin JM, Walker EA, Nathan DM, Diabetes Prevention Program Research Group. Reduction in the incidence of type 2 diabetes with lifestyle intervention or metformin. $N$ Eng J Med 2002. 346(6):393-403.

44. Pitsavos C, Panagiotakos DB, Chrysohoou C, Kavouras S, Stefanadis C. The associations between physical activity, inflammation, and coagulation markers, in people with metabolic syndrome: the ATTICA study. Eur I Cardiovasc Prev Rehabil 2005. 12:151-158.

45. US Department of Health and Human Services. Physical Activity and Health: a Report of the Surgeon General. Atlanta, GA, US Department of Health and Human Services, Centers for Disease Control and Prevention, National Center for Chronic Disease Prevention and Health Promotion, 1996.

46. Jakicic JM, Winters C, Lang W, Wing RR. Effects of intermittent exercise and use of home exercise equipment on adherence, weight loss, and fitness in overweight women. JAMA 1999. 282:1554-1560.

47. Kokkinos PF, Narayan P, Colleran JA, Pittaras A, Notargiacomo L, Reda D, Papademetriou V. Effects Of Regular Exercise On Blood Pressure And Left Ventricular Hypertrophy In African-American Men With Severe Hypertension. N Engl J Med 1995. 333:1462-1467.

48. Burt VL, Whelton P, Roccella EJ. Prevalence of hypertension in the US adult population. Results from the Third $\mathrm{Na}$ tional Health and Nutrition Examination Survey, 1988-1991. Hypertension 1995. 25(3):305-313.

49. Eaton CB, Lapane KL, Garber CE. Physical activity physical fitness and coronary heart disease risk factors. Med Sci Sports Exerc 1995. 27:340-346.

50. Hsieh SD, Yoshinaga H, Muto T, Sakurai Y. Regular physical activity and coronary risk factors in Japanese men. Circulation 1998. 97:661-665.

51. Bijnen FC, Feskens EJ, Caspersen CJ. Physical activity and cardiovascular risk factors among elderly men in Finland, Italy and the Netherlands. Am J Epidemiol 1996. 143:553-561.

52. Ford ES. Does exercise reduce inflammation? Physical activity and C-reactive protein among U.S. adults. Epidemiology 2002. 13:561-568.

53. King DE, Carek P, Mainous AG 3rd, Pearson WS. Inflammatory Markers and Exercise: Differences Related to Exercise Type. Med Sci Sports Exerc 2003. 35:575-581.

54. Abramson JL, Vaccarino V. Relationship between physical activity and inflammation among apparently healthy middleaged and older US adults. Arch Intern Med 2002. 162:1286-1292.

55. MacAuley D, McCrum EE, Stott G, Evans AE, McRoberts B, Boreham CA, Sweeney K, Trinick TR. 
Physical activity, physical fitness, blood pressure, and fibrinogen in the Northern Ireland health and activity survey. J Epidemiol Community Health 1996. 50:258-263.

56. Danesh J, Collins R, Appleby P. Association of fibrinogen, C-reactive protein, albumin, or leukocyte count with coronary heart disease: meta-analyses of prospective studies. JAMA 1998. 279:1477-1482.

57. Panagiotakos DB, Pitsavos C, Chrysohoou C, Kavouras S, Stefanadis C. The associations between leisure-time physical activity and inflammatory and coagulation markers related to cardiovascular disease: the ATTICA Study. Prev Med 2004. 40(4):432-437.

58. Koh KK. Inflammatory markers and the metabolic syndrome. $J$ Am Coll Cardiol 2005. 46:1978-1985.

59. Roberts CK, Barnard RJ. Effects of exercise and diet on chronic disease. J Appl Physiol 2005. 98:3-30.

60. Stone N, Saxon D. Approach to treatment of the patient with metabolic syndrome. Lifestyle therapy. Am J Cardiol 2005. 22:15E-21E.

61. Haffner S. Diabetes and the metabolic syndrome. When is it best to intervene to prevent? Atherosclerosis 2006. 7:S3-S10.

62. Eriksson KF, Lindgarde F. No excess 12 -year mortality in men with impaired glucose tolerance who participated in the Malmo Preventive Trial with diet and exercise. Diabetologia 1998. 41(9):1010-1016.

63. Pan XR, Li GW, Hu YH, Wang JX, Yang WY, An ZX, Hu ZX, Lin J, Xiao JZ, Cao HB, et al. Effects of diet and exercise in preventing NIDDM in people with impaired glucose tolerance. The Da Qing IGT and Diabetes Study. Diabetes Care 1997. 20(4):537-544.

64. Wein P, Beischer N, Harris C, Permezel M. A trial of simple versus intensified dietary modification for prevention of progression to diabetes mellitus in women with impaired glucose tolerance. Aust N Z J Obstet Gynaecol 1999. 39(2):162-166. 